\title{
Tracing the past and future of a mighty river
}

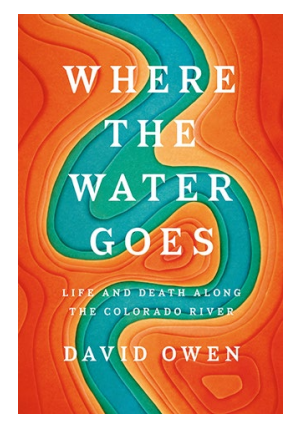

\author{
Where the Water \\ Goes: Life and \\ Death Along the \\ Colorado River
}

By David Owen

RIVERHEAD BOOKS: 2017. 288 PP. $€ 24$

\footnotetext{
T
} he American Southwest may have experienced a severe scarcity of precipitation for the first half of this decade, but there has been no dearth of books about that drought and what it portends for the future of a region that covers one fifth of the continental United States and is home to some 50 million people. The vast majority of those people, and the farmland in that region, depend on one river: the Colorado. David Owen decided to follow its length to bring the river, and those who live along it, to life.
Much of the farmland in the Colorado River basin is there only because of reclamation projects funded by the federal government, bringing subsidized water to fields of lettuce in the desert or alfalfa in the mountains. That water is allocated on the basis of 'first in time, first in right', where senior rights-holders are allowed to keep using that water in perpetuity, regardless of how economically, ecologically, or socially valuable that use is. One of the more counterintuitive findings that Owen brings us, however, is that more efficient use of irrigated water would actually cause more problems for the basin. Water that is 'wasted' through flood irrigation actually helps to recharge aquifers and the Colorado River itself, but the less water that is used for irrigation means (temporarily) more for cities, which means more people living permanently in a region that already is overstretched as it is.

Where the Water Goes is more a travelogue than the in-depth hydrological tome that some readers may be expecting, but Owen provides much needed historical context regarding how and why the Colorado River is one of the most overused and over-litigated waterways on Earth. He cogently analyses the various interest groups and paradoxes at play regarding this vast ecological puzzle, with agriculture, ranching, suburbs, and endangered species all competing for a dwindling river. The first-person account and visits with residents, engineers, and activists on the ground may seem too small scale for such a grand river. The Colorado River, however, has always defied scale. Owen's attempt to provide understanding is akin to John Wesley Powell's first descent of the Grand Canyon, 150 years ago: awe-inspiring, terrifying, and likely to be ignored by policy makers and residents alike until it is too late.

\section{Reviewed by Ryan Scarrow}

Published online: 7 November 2017 https://doi.org/10.1038/s41477-017-0055-z 